\title{
EŞDEĞER DOĞRUSAL VE DOĞRUSAL OLMAYAN YAKLAŞIMLARA GÖRE SİSMİK YÜK ETKİSINNDEKİ ZEMİNLERDE DAVRANIŞ ANALİZi
}

\author{
Ebru CIVELEKLER ${ }^{1}$, Kamil B. AFACAN²*, D. Volkan OKUR ${ }^{3}$ \\ ${ }^{1}$ Eskişehir Osmangazi Üniversitesi, Mühendislik-Mimarlık Fakültesi, İnşaat Mühendisliği Bölümü, Eskişehir, \\ ORCID No : http://orcid.org/0000-0002-5528-3453 \\ 2 Eskişehir Osmangazi Üniversitesi, Mühendislik-Mimarlık Fakültesi, İnşaat Mühendisliği Bölümü, Eskişehir, \\ ORCID No : http://orcid.org/0000-0002-3667-4432 \\ 3 Eskişehir Osmangazi Üniversitesi, Mühendislik-Mimarlık Fakültesi, İnşaat Mühendisliği Bölümü, Eskişehir, \\ ORCID No : http://orcid.org/0000-0002-3416-8202
}

\begin{tabular}{|c|c|}
\hline Anahtar Kelimeler & Öz \\
\hline $\begin{array}{l}\text { Bir Boyutlu } \quad \text { Eşdeğer } \\
\text { Doğrusal Analiz, } \\
\text { Bir Boyutlu Doğrusal } \\
\text { Olmayan Analiz, } \\
\text { Zemin Davranış Analizleri. }\end{array}$ & 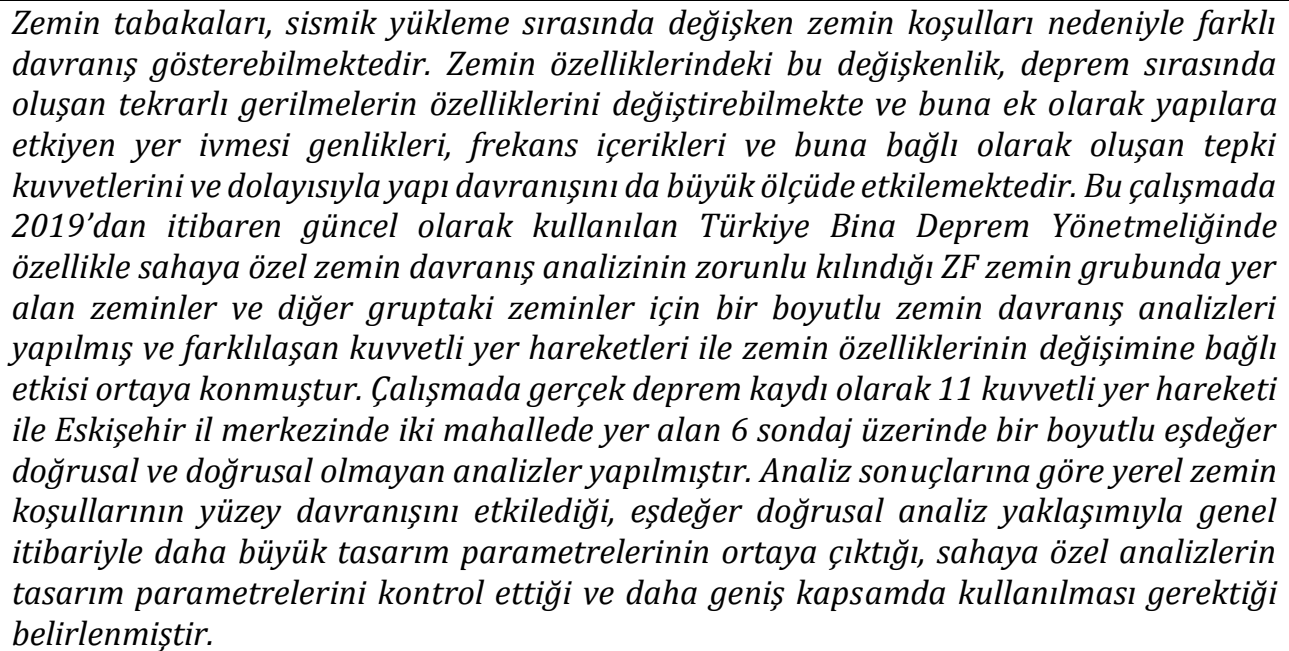 \\
\hline
\end{tabular}

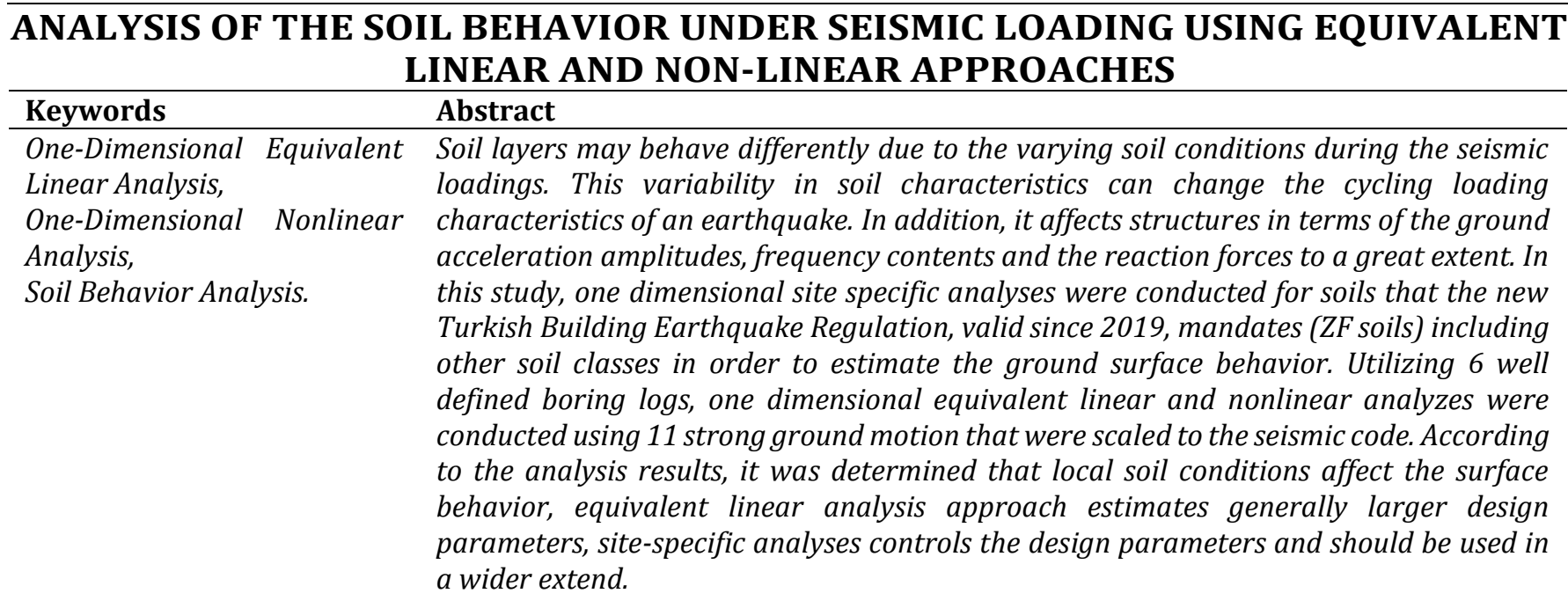

${ }^{*}$ Sorumlu yazar; e-posta : kafacan@ogu.edu.tr

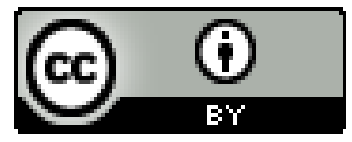

Bu eser, Creative Commons Attribution License (http://creativecommons.org/licenses/by/4.0/) hükümlerine göre açık erişimli bir makaledir.

This is an open access article under the terms of the Creative Commons Attribution License (http://creativecommons.org/licenses/by/4.0/). 


\begin{tabular}{llll}
\hline Araştırma Makalesi & & Research Article & \\
Başvuru Tarihi & $: 12.12 .2020$ & Submission Date & $: 12.12 .2020$ \\
Kabul Tarihi & $: 17.05 .2021$ & Accepted Date & $: 17.05 .2021$ \\
\hline
\end{tabular}

\section{Giris}

Dünyanın aktif deprem kuşakları üzerinde yer alan ülkemizde yaklaşık son 20 yılda; 17 Ağustos 1999 Kocaeli, 12 Kasım 1999 Düzce, 23 Ekim 2011 Van, 24 Ocak 2020 Elazığ ve 30.10.2020 İzmir olmak üzere ortabüyük şiddette depremler meydana gelmiștir. Bu depremler özellikle yerleşim alanlarında büyük yapısal yıkımlara ve can kayıplarına neden olmuştur.

Çalıșma alanı olan Eskişehir'de ise 1999 Kocaeli ( $\left.\mathrm{M}_{\mathrm{w}}: 7.4\right)$ depreminde 1 bina deprem anında 4 bina deprem sonrası yıkılmış ve resmi kayıtlara göre 86 kişi hayatını kaybetmiştir. Bunun yanı sıra Eskişehir merkezli kaydedilen 20 Şubat 1956 tarihli (M $\mathrm{M}_{\mathrm{w}}$ 6.4) depremde, bölgede can ve mal kaybına neden olmuştur.

Afet zararlarının azaltılması ve depreme dayanıklı yapı tasarımında zemin tabakalarının sismik yükler altındaki davranışının belirlenmesi ve buradan hareketle yapısal tasarımın yapılması gerekmektedir. Zemin tabakalarının farklılaşması kuvvetli yer hareketinin özelliklerini değiştirmektedir.

Önceki çalışmalarda yerel zemin koşullarının farklılaşması olarak açıklanan bu durumun kuvvetli yer hareketinde ve yapılarda meydana gelen hasarlardaki etkisi uzun zamandan beri bilinmektedir. MacMurdo (1824) 1819'da Hindistan Cutch bölgesinde meydana gelen depremde anakaya üzerinde bulunan yapıların daha yumuşak zeminde bulunan yapılara göre daha az hasar aldığını gözlemlemiştir. Gutenberg (1957), Borcherdt (1970), Kanai (1954, 1959) gibi araştırmacılar küçük manyitüdlü depremlerden ve arazide yaptıkları mikrotremör çalıșmaları sonucunda elde ettikleri verilerden, yumuşak zeminlerde sağlam zeminlere göre yüzeyde daha büyük ivme değerlerinin oluştuğunu belirlemişlerdir. Bunun yanı sıra deprem hasarında yerel zemin özelliklerinin depremin genlik, frekans ve süresini etkilediği farklı araştırmalarda ortaya koymuştur (Kramer, 1996). Kocaeli (1999) depreminde, alüvyon zemin tabakalarından oluşan Adapazarı merkezde, daha sağlam zemin tabakalarına inşa edilmiş üç-dört katlı binalarda yumuşak zeminlerde inşa edilmiş yapılara göre daha az hasar oluştuğu ve yumuşak zeminlerdeki hasarın zemin büyütmesinden kaynaklı olabileceği ön görülmüştür (Bakir ve diğ., 2002). Akgün ve diğ., (2015) İzmir-Bayraklı zemininde anakaya tanımına göre $V_{s}>760 \mathrm{~m} / \mathrm{sn}$ değerlerinin ortalama $300 \mathrm{~m}$ derinlikten sonra oluştuğunu, zemin yüzeyinden itibaren ortalama $300 \mathrm{~m}$. kalınlık içindeki $\mathrm{V}_{\mathrm{s}}=300 \mathrm{~m} / \mathrm{sn}$ olduğunu, zemin yüzeyine yakın derinliklerde ise çok düşük kayma dalgası hız değerlerinin görüldüğünü belirlemișlerdir. $\mathrm{Bu}$ da ülkemizde son meydana gelen 30.10.2020 İzmir depreminde en fazla hasarın Bayraklı ilçesinde meydana gelmesinin nedenlerinden bir tanesinin zemin özellikleri olduğunun açık göstergesidir.

Depreme dayanıklı yapı tasarımında, kuvvetli yer hareketi sonucu yapıya etkiyecek sismik kuvvetlerin belirlenmesi için, deprem yönetmeliklerinde tanımlanan tasarım spektrumları kullanılmaktadır. Yönetmeliklerde verilen tasarım spektrumları ile yapıların doğal titreşim periyodunu dikkate alarak deprem etkisi altında yapıda oluşan yatay ve düşey yükler belirlenmektedir. Tasarım spektrumları, sahanın sismik özelliklerini ve zemin koşullarını dikkate alarak farklı deprem kuvvetlerine verdiği tepkinin maksimum değerlerinden oluşur. Tasarım spektrumları yeni inşa edilecek yapılarda deprem yükünü belirlemek amacıyla kullanılmakta, tepki spektrumlarına düzgünleștirilmiş bir zarf eğrisi uydurulmasıyla elde edilmektedir (Kale, 2017).

Ülkemizdeki mevcut Bina Deprem Yönetmeliklerinde yerel zemin koşullarının belirlenerek tasarlanması çalıșmaları ilk olarak 1975 yönetmeliği ile başlamıștır. Ancak 1998 ve 2007 yönetmeliklerinde bu konuda pek bir değişiklik yapılmamış; geoteknik deprem mühendisliği alanında artan bilgi birikimi ve çalışmalar sonucunda günümüz Bina Deprem Yönetmeliğine konu dâhil edilmiştir.

2019'dan itibaren güncel olarak kullanılan son yayınlanan Türkiye Bina Deprem Yönetmeliği (2018)'de, önceki yönetmeliklere göre özellikle sahaya özel yerel zemin sınıflarının belirlenmesi kısmı genişletilerek deprem yer hareketi spektrumlarının yapının bulunduğu konuma, faya uzaklığına ve zemin özelliklerine göre hesaplanması önerilmektedir. TBDY (2018)'in 16.5.1.3. bölümünde “yerel zemin sınıfları tablosunda $\mathrm{ZF}$ zemin sinıf olarak tanımlanan zeminlerin, yüzeydeki deprem yer hareketini belirlemek amacıyla sahaya özel zemin davranış analizlerinin yapilması zorunludur" ibaresi yer almaktadır. Ayrıca bu tür analizler gerekli görülürse diğer sınıflardaki zeminler için de yapılması önerilmektedir.

Zemin davranış analizleri "eşdeğer doğrusal zemin davranışı analizleri" ve "doğrusal olmayan zemin davranışı analizleri” olarak farklı iki şekilde yapılmaktadır. Bazı araştırmalara göre zemin davranış analizinde "eşdeğer doğrusal" veya "doğrusal olmayan" yöntemin seçiminde, zemin özellikleri ve anakaya 
deprem hareketinin karakteristik özellikleri karar vericidir. Örneğin tekrarlı gerilmelerin göreceli olarak düşük olduğu durumlarda eşdeğer doğrusal analiz yöntemi önerilirken, tekrarlı gerilmelerin büyük olduğu durumlarda doğrusal olmayan analiz yöntemi ile daha gerçekçi sonuçlara ulaşılmıştır (Pruiksma, 2016; Carlton ve Tokimatsu, 2016; ve Selçuk ve diğ., 2007). Bu durum ise zeminlerin düşük gerilme durumlarında elastik, büyük gerilme genliklerinde ise elasto-plastik ve plastik davranış göstermesi ile açıklanmaktadır (Akdoğan, 2019). TBDY 2018, en zayıf zemin sınıfı olarak tanımlanan ZF sınıfında sıvılaşma ihtimali olan zeminler için; davranışın elasto-plastik ve plastik olma ihtimali nedeniyle bir boyutlu doğrusal olmayan zemin davranış analiz çalışmalarını önermektedir.

$\mathrm{Bu}$ çalışmada Eskişehir şehir merkezinde nüfusun ve yapılașmanın yoğun olduğu; Eskișehir'in yüzölçümü olarak büyük mahalleleri arasında yer alan Sazova ve Şeker mahalleleri çalışma alanı olarak belirlenmiş ve bu iki mahalleyi temsil eden 6 sondaj için analizler yapılmıştır. Çalışmada ZC, ZD, ZE ve ZF yerel zemin sınıfına sahip 6 sondajda TBDY (2018)' in önerdiği gibi 11 kuvvetli yer hareketi kullanılarak eşdeğer doğrusal ve doğrusal olmayan analizler yapılmıştır. Davranış analizi sonucu elde edilen veriler TBDY (2018) ve AFAD interaktif web uygulamasında konuma bağlı olarak elde edilen spektrum değerleri ile karşılaştırılmıştır.

\section{Materyal ve Yöntem}

\subsection{Zaman tanım alanında deprem yer hareketinin tanımlanması}

Depremlerin sahaya özgü etkilerinin değerlendirilmesi ve belirlenebilmesi için gerekli parametreler kuvvetli yer hareketinin özelliklerini oluşturmaktadır. TBDY 2018 2. bölümünde bina taşıyıcı sistemlerinin zaman tanım alanında bir, iki veya üç boyutlu deprem hesabında gerekli kuvvetli yer hareketinin tanımlanması için kullanılacak deprem kayıtlarının seçimi ve basit ölçeklendirme yöntemi kullanılması önerilmiştir. Ayrıca belirli bir yıl için, aşılma olasılığı ve tekrarlanma periyoduna bağlı tanımlanan Deprem Hareket Seviyeleri DD-1, DD-2, DD-3 ve DD-4 olmak üzere 4 seviye için verilmiştir.

TBDY 2018'de dört guruba ayrlan deprem yer hareketi düzeylerine göre DD-1; oluşma sıklığ 1 az olan en büyük deprem yer hareketini temsil etmekte, büyüklüklerine göre azalarak DD-2, DD-3 ve DD-4 olarak sinıflandırılmaktadır. DD-2; standart tasarım deprem yer hareketi olarak tanımlanmaktadır. Bu nedenle bina tasarımında (konut, işyeri vb.) sıklıkla kullanılan deprem yer hareketi düzeyi DD-2'dir. Ancak hastane, okul ve nükleer santral gibi önem derecesi yüksek yapıların tasarımı için DD-1 deprem yer hareketi düzeyi kullanılmaktadır. AFAD’ın Türkiye Deprem Tehlike Haritası verilerinde, yapı tasarımında Eskişehir için önerdiği seviye de DD-2'dir.

$\mathrm{Bu}$ çalışmada araştırma ve yayın etiğine uyulmuştur. Çalışma kapsamında analizlerin yapıldığı 6 sondajın bulunduğu Sazova ve Şeker mahalleri için AFAD tarafindan hazırlanan Türkiye Deprem Tehlike Haritaları İnteraktif Web Uygulamasında DD-2 yer hareketi düzeyi için deprem karakteristikleri elde edilmiş ve bir tabloda toplanmıştır ( Tablo 1).

Tablo 1

Çalışmada Kullanılan Sondajların Bulunduğu Mahallelere Ait AFAD Türkiye Deprem Tehlike Haritasından Belirlenen Deprem Karakteristikleri

\begin{tabular}{ccccc} 
Mahalle & $\begin{array}{l}\text { Zemin } \\
\text { Sinıf }\end{array}$ & S & PGA(g) & PGV(cm/sn) \\
\hline Sazova & ZE & 0.966 & 0.297 & 17.890 \\
Şeker & ZE & 0.954 & 0.282 & 17.018 \\
\hline
\end{tabular}

Açılklama: SDS: Yatay elastik tasarım spektrumu,

PGA (g): pik yer ivmesi, PGV (cm/sn): pik yer hızı

\subsection{Analizlerde kullanılan deprem kayıtlarının seçimi ve ölçeklendirilmesi}

TBDY 2018'de depreme dayanıklı yapıların inşasında kullanılacak deprem kayıtlarının seçiminde, tasarıma esas kuvvetli yer hareketi düzeyi ile uyumlu deprem büyüklükleri, faya uzaklıkları, kaynak mekanizmaları ve yerel zemin özelliklerinin dikkate alınması önerilmektedir.

Çalıșmada eșdeğer doğrusal ve doğrusal olmayan analizler kapsamında gerçek deprem kayıtları kullanılmıştır. Analizlerde kullanılan 11 ivme kaydı Pasifik Deprem Mühendisliği Araştırma Merkezi, PEER veri tabanından elde edilmiștir. 11 ivme kaydına ait veriler sismik risk, zemin özelliği, fay tipi, deprem büyüklüğü gibi özelliklere bağlı olarak seçilmiştir. Analizlerde kullanılan 11 deprem verisi $\mathrm{M}_{\mathrm{w}}>5.5$ büyüklüğe sahip ve doğrultu atımlı fay üzerinde meydana gelmiş, zemin özellikleri ile sismik risk durumu (Fay uzaklı̆̆ı: 0-40 km, $\mathrm{V}_{\mathrm{s} 30}: 360-760$ ) yakın olduğu varsayılan 11 farklı istasyondan alınmış verilerdir ve bu veriler Tablo 2'de verilmiştir. 
Tablo 2

Çalışmada Kullanılan Yer Hareketi Verileri (PEER, 2006)

\begin{tabular}{llll} 
Deprem & Yıl & İstasyon & Büyüklük \\
\hline Erzincan & 1992 & Erzincan & 6.69 \\
Kocaeli & 1999 & Yarımca & 7.2 \\
Düzce & 1999 & Düzce & 7.14 \\
Coyote Lake & 1979 & SJB & 5.7 \\
Imperial Valley & 1979 & Calipatria & 6.5 \\
Imperial Valley & 1940 & El Centro & 6.9 \\
& & & \\
Loma Prieta & 1989 & Gilroy 3 & 6.9 \\
Loma Prieta & 1989 & Gilroy 4 & 6.9 \\
Parkfield & 1966 & Benioff & 6.1 \\
Denali & 2002 & TAPS & 7.9 \\
Darfield & 2010 & DSLC & 7.0 \\
\hline
\end{tabular}

Çalışmada eşdeğer doğrusal ve doğrusal olmayan analizler Deepsoil 6.1. yazılımı ile gerçekleștirilmiștir.
Bu çalışmada tercih edilen Deepsoil yazılımı, bir boyutlu zemin davranış analizleri çalışma prensibine dayalı olarak ilk 1998 yılında geliștirilmiștir. Deepsoil ile hem frekans hem de zaman tanım alanında çözümlemeler ile hem eşdeğer doğrusal hem de doğrusal olmayan analizler yapılabilmektedir (Hashash ve diğ., 2016). 6 sondaj üzerinde 11 farklı kuvvetli yer hareketi verisi kullanılarak, toplam 66 eşdeğer doğrusal ve 66 doğrusal olmayan analiz gerçekleştirilmiştir. Çalışma alanındaki mahallelere ait PGA değerleri Şeker mahallesinde $0.282 \mathrm{~g}$ ve Sazova mahallesinde $0.297 \mathrm{~g}$ olarak öngörülmektedir (Tablo 1). Bu nedenle çalışmada kullanılan deprem kayıtları PGA $=0.3 \mathrm{~g}$ ve DD-2 durumuna göre ölçeklendirilerek analizler yapılmıştır. Analizlerde kullanılan ölçeklendirilmiş anakaya ivmeleri Şekil 1'de gösterilmiştir.

Görüldüğü üzere depremler, frekans içeriği, süre, baskın pik sayısı gibi birçok konuda birbirlerinden ayrılmakta ve çeşitliliği yansıtmaktadır. Sahaya özel analizlerde kullanılacak anakaya ivmelerinin birbirlerinden çok farklı olması yüzeyde tahmin edilecek davranışın daha geniş bir aralıkta olmasına olanak verdiği için büyük önem arz etmektedir.
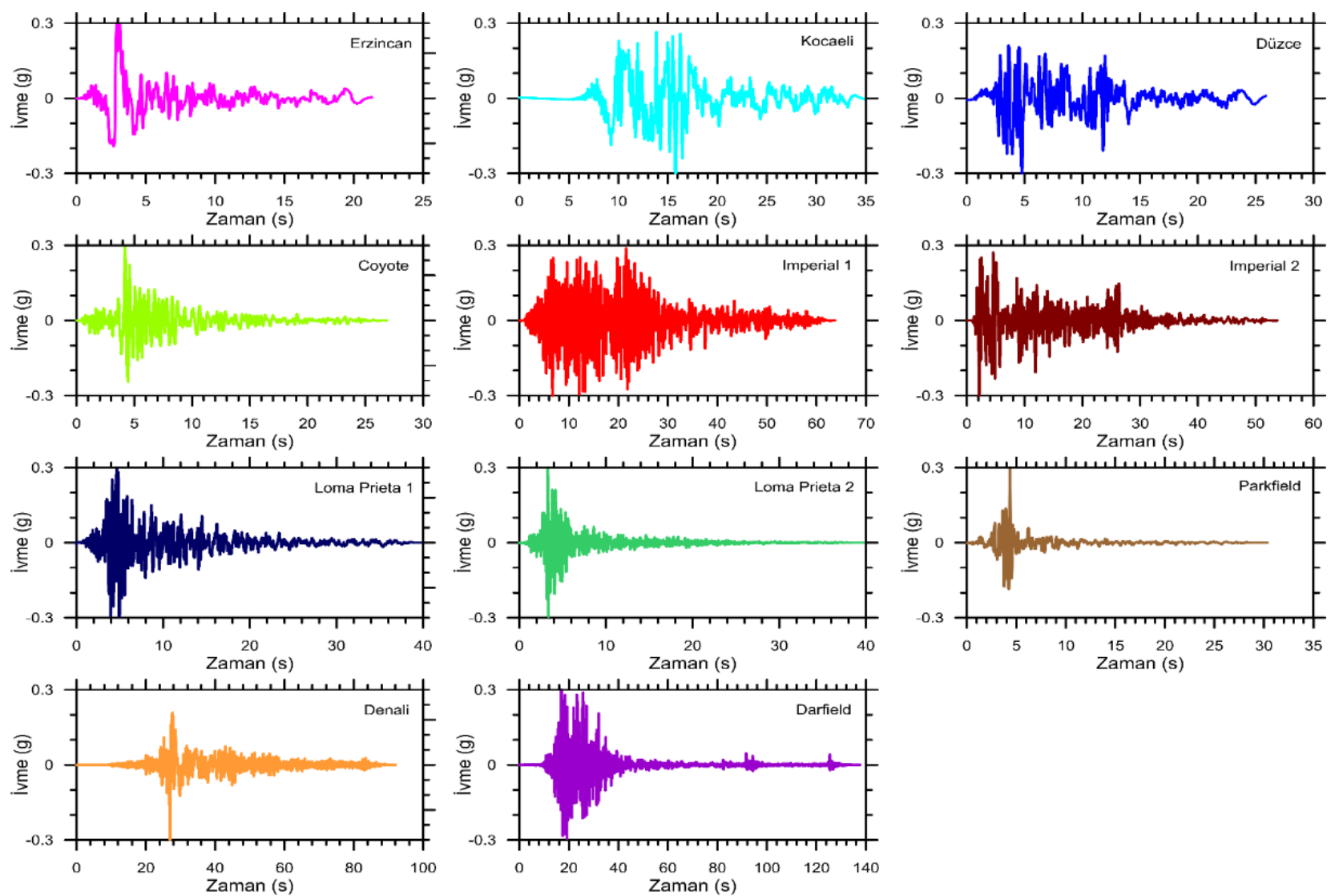

Şekil 1. Eşdeğer Doğrusal Ve Doğrusal Olmayan (Nonlinear) Analizlerde Kullanılan PGA=0.3 g Olarak Ölçeklendirilmiş Deprem Verileri 


\section{3. Çalışmada kullanılan sondajların zemin özellikleri}

Sazova ve Şeker mahalleleri Eskișehir şehir merkezinde yer almakta olup, şehir merkezinde Alüvyon zemin yayılım göstermektedir. (Esen ve diğ., 1976; Gözler Cevher ve Küçükayman, 1985; Ölmez, Demirel ve Uzel, 1986; Yıldırım ve Gürsoy, 1985; Sariiz ve Oruç, 1989; Gözler, Cevher, Ergül ve Asutay, 1996.). Eskişehir şehir merkezinde yayılım gösteren en genç formasyon olan Alüvyon, bazı araştırmacılar tarafından eski alüvyon ve yeni alüvyon olarak da ikiye ayrılmaktadır. Eski Alüvyon, daha yaşlı formasyonlara ait kil, silt, kum ve çakıl seviyelerinden oluşmaktadır (Orhan, 2005). Yaşı en genç tanımlanmış Yeni Alüvyon ise, Sarısu deresi ve Porsuk Çayı'nın getirdiği malzemelerden oluşmaktadır. Kuvaterner yaşlı bu Alüvyon içinde kil, silt, kum ve çakıl seviyeleri bulunmaktadır (Akdeniz ve diğ. 2011; Civelekler ve Pekkan., 2021; Tün, 2013) ve Şekil 2'de sunulmuştur.

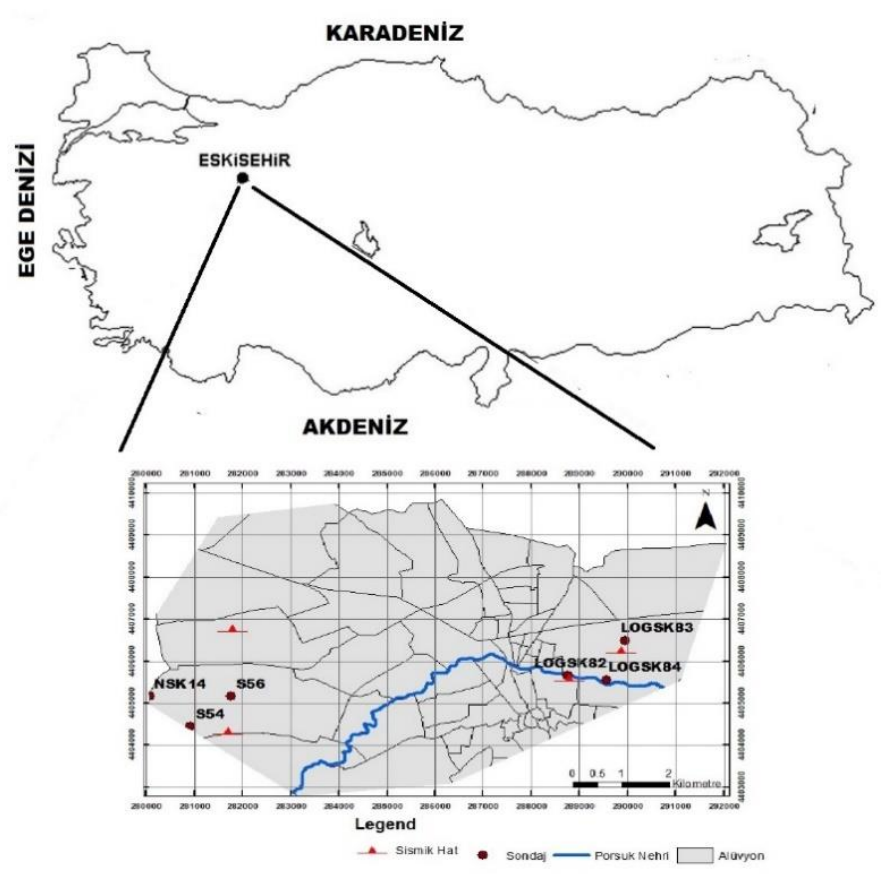

Şekil 2. Çalışma Alanı Lokasyon Haritası

Çalışmada Şeker mahallesinde LOGSK82, LOGSK83, LOGSK84 ve Sazova mahallesinde NSK14, S54, S56 sondajları için analizler yapılmıştır. TBDY (2018)'e göre NSK14 ZC, S54 ZD, S56 ZE ve LOGSK82 ve LOGSK84 ZF, LOGSK83 ZE yerel zemin sınıfında yer almaktadır (Civelekler, 2020). TBDY 2018'e göre ise ZF zemin sınıfı olarak belirlenmiş olan LOGSK82 ve LOGSK84 sondajlarının kesitlerine bakıldığında toplam kalınlığı 8 metreden fazla yüksek plastisiteli kil tabakalarından oluşmakta ve yeraltı suyu seviyesi değerlerinin 5-6 metre seviyelerinde değiştiği görülmektedir. Şekil 3'de de görüldügü üzere $\left(\mathrm{N}_{60}\right)_{30}$ darbe sayılarının LOGSK84 sondajinda ilk 4 metre için 8, LOGSK82'de ise 4 metrede 10 değerlerindedir. Çalışmada kullanılan sondajların zemin özellikleri Tablo 3'de verilmiştir. Sondajlar incelendiğinde aslında hepsinin benzer zeminler içerdiği düşünülebilir; fakat anakayadan başlayan sismik hareketin geçiş tabakalarının empedans özelliklerine bağlı olarak değiștiği göz önüne alındığında, tabakalanmanın etkisinin de sonuçlara yansıyacağı öngörülmektedir.

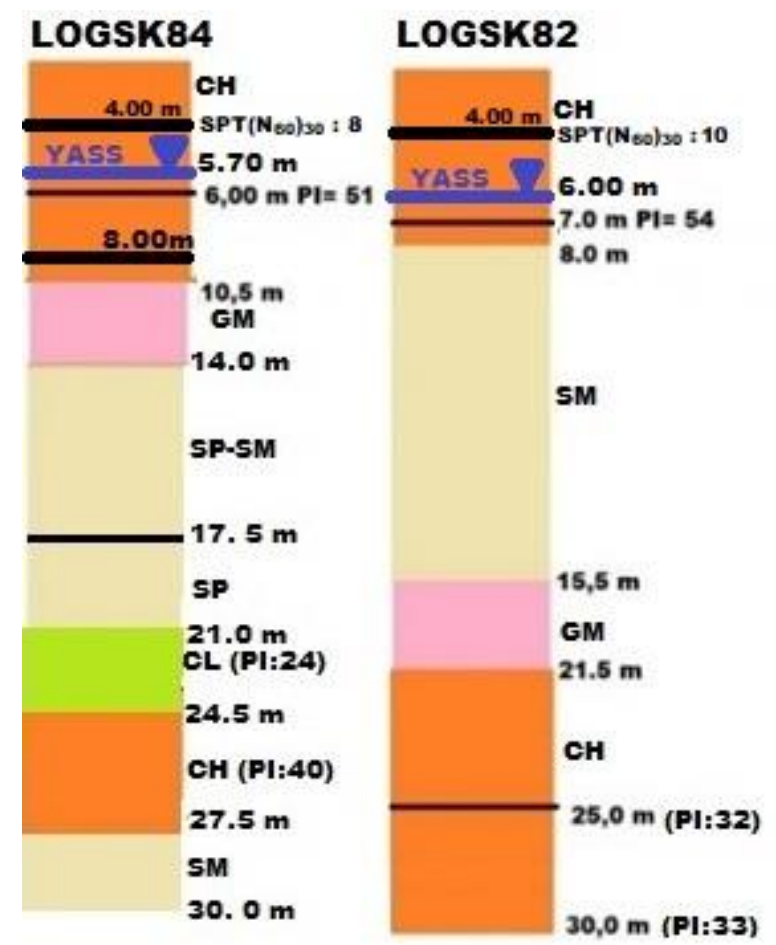

Şekil 3. LOGSK84 ve LOGSK82 Sondajların Kesit Örneği 
Tablo 3

Çalıșma Alanı Sondajlarının Birleștirilmiș Zemin Sınıflandırma Sistemine Göre Belirlenmiș Zemin Sınıfları

\begin{tabular}{lllllll} 
Derinlik & S54 & S56 & NSK14 & LOGSK82 & LOGSK83 & LOGSK84 \\
\hline $0.00-3.50 \mathrm{~m}$ & CL (PI:12) & SM & CH (PI:21) & CH (PI:49) & CH (PI:43) & CH (PI:50) \\
3.50-7.0 m & CL (PI:18) & SM & CL (PI:20) & CH (PI:54) & CH (PI:32) & CH (PI:52) \\
$7.00-10.5 \mathrm{~m}$ & CH (PI:29) & SM & CH (PI:24) & SM & SM & CH (PI:31) \\
$10.5-14.0 \mathrm{~m}$ & CL (PI:18) & SM & SW-SM & SM & SM & GM \\
$14.0-17.5 \mathrm{~m}$ & CL (PI:18) & CL (PI:22) & SM & GM & SM & SP-SM \\
$17.5-21.0 \mathrm{~m}$ & CL (PI:20) & MH (PL: 26) & SP & GM & SM & SM \\
$21.0-24.5 \mathrm{~m}$ & SC & MH (PI:36) & SM & CH (PI:32) & CH (PI:44) & CL (PI:24) \\
$24.5-27.5 \mathrm{~m}$ & SM & MH (PI:37) & CL (PI:18) & CH (PI:28) & CH (PI:34) & CH (PI:40) \\
$27.5-30.0 \mathrm{~m}$ & SM & MH (PI:24) & CH (PI:23) & CH (PI:33) & SM & SM \\
\hline
\end{tabular}

Güney ve diğ., (2013) ve Mutlu (2012) çalışmalarından elde edilen sismik kırılma-yansıma verileri de kullanılarak, çalışma kapsamındaki 2 mahalleyi (Sazova ve Şeker mahalleleri) temsil eden zeminin kayma dalgası hızı değerleri ve tabakalanma özellikleri elde edilmiş ve çalışmada kullanılan bu veriler örnek olarak Şekil 4 ve Şekil 5 de sunulmaktadır. Burada rijit tabakaların hızlıca rastlanıldığı tabakalanmanın olduğu gibi, daha derin tabakalarda karşılaşıldığı grafiklerden de anlaşılmaktadır. Yüzey tabakası hariç kayma dalgası hızı profillerinin eğimli olduğu görülmektedir. Bu da tabaka kalınlığının kısa mesafelerde ne denli değiştiğini göstermektedir.

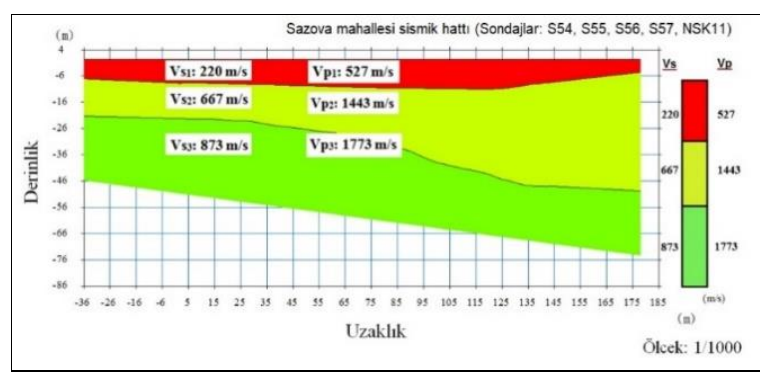

Şekil 4. Sazova Mahallesi Sismik Kırılma Hattı Hız Kesiti Örneği

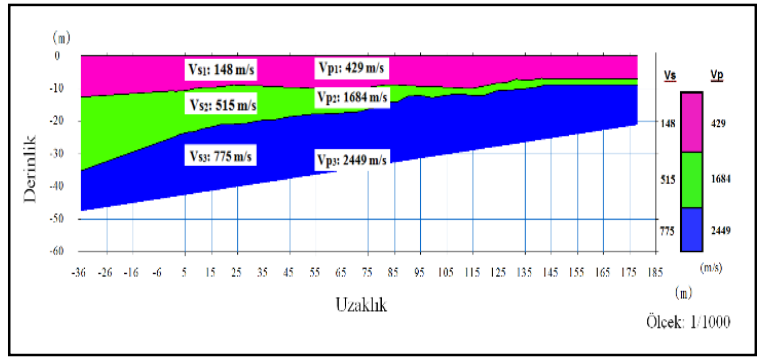

Şekil 5. Şeker Mahallesi Sismik Kırılma Hattı Hız Kesiti Örneği

\subsection{Zemin Davranış Analizleri}

Zemin davranış analizleri çalışmaları ikiye gruba ayrilabilir

1) Frekans alanı analizleri (eşdeğer doğrusal zemin davranışı analizleri)

2) Zaman alanı analizleri (doğrusal olmayan zemin davranıșı analizleri)

Çalışma kapsamında kullanılan Deepsoil yazılımında sinırsız sayıda zemin tabakası tanımlanabilmekte ve her bir tabaka için ivme, gerilme, gerilme-zaman, Fourier davranış spektrumu, Fourier amplifikasyon oranı spektrumu ve davranış spektrumları elde edilmektedir.

\subsubsection{Bir Boyutlu Eşdeğer Doğrusal Analiz}

Deprem dalgalarının yayılması sırasında oluşan deformasyonlar küçük gerilme seviyelerinde elastik davranışa ve yüksek gerilme seviyelerinde ise elastik olmayan davranışa neden olur (Akın, 2009). Eşdeğer 
doğrusal modellerde zeminler doğrusal malzemeler olarak kabul edilir. Doğrusal olmayan modeller için birim deformasyona bağlı rijitlik ve sönümleme parametreleri hesaba katılmaktadır (Okur ve Ansal, 2009).

Çalışmada 6 sondaj için; zemin tabakasının kalınlığı, birim hacim ağırlığı, zemin sınıfı ve kayma dalgası hızı özelliklerine bağlı olarak tabakalar halinde $30 \mathrm{~m}$ derinlik için tanımlamalar yapılmıştır. Eşdeğer doğrusal ve doğrusal olmayan analizlerde birim deformasyon ve malzeme parametreleri için ince daneli (kil-silt) zeminler için Darendeli 2001, iri daneli zeminler için (kum-çakıl) Seed ve Idriss 1991 ortalama eğrileri kullanılmıştır.

\subsubsection{Bir Boyutlu Doğrusal Olmayan Analiz}

Sismik hareket sonucunda oluşan tekrarlı yükler altında zeminin davranışı doğrusal değildir. Doğrusal olmayan yaklaşımda zeminin histeretik gerilme-şekil değiştirme ilişkisi dikkate alınmakta ve bu nedenle doğrusal olmayan yaklaşım daha gerçekçi olarak kabul edilmektedir (Bolisetti, Whittaker, Mason, Almufti ve Willford, 2014). Doğrusal olmayan zemin davranış analizleri; zaman alanlı analizlerdir ve gerilme-şekil değiștirme karakteristiklerini kullanan yaklaşımlardır. Yüksek genliklere sahip yer hareketlerinde zemin özelliklerine bağlı olarak farklı kayma modülü ve sönüm oranı değerleri elde edilmiş zeminlerin, sismik yükler altında doğrusal davranmayacağı dinamik laboratuvar deneyleri ile de kanıtlanmıştır (Roca, Oliveira, Ansal ve Figueras, 2006).

Zemin davranış analizlerinde temel prensip, 1B (boyutlu) eşdeğer doğrusal yaklaşımda tabakaların yatay ve sonsuz yönde yayılım gösterdiği ve her bir zemin tabakası için kayma modülü $(G)$ ve sönüm oranının (D) sabit olduğu kabul edilir. Ancak doğrusal olmayan yaklaşımda tekrarlı yükler altında her bir zemin tabakası için gerilme-deformasyon seviyesine bağlı olarak kayma modülü sönüm oranı sürekli değişmektedir.

\section{Bulgular ve Tartışma}

\subsection{Eşdeğer Doğrusal Analiz Çalışmaları Sonuçları}

\subsubsection{Zemin yüzeyinde oluşan ivme değerleri}

Yapılan analizler sonucunda öncelikle 6 sondaj için ivme zaman grafikleri oluşturulmuştur. Analizlerde Sazova mahallesinde bulunan üç sondaj için pik ivmelerin S54 ve S56 sondajlarında yaklaşık 0.6 g olduğu ve pik ivmeye 2.5 saniyede ulaştığı belirlenmiştir. NSK14 sondajında ise 0.35 saniyede maksimum pik ivme $0.4 \mathrm{~g}$ olarak elde edilmiştir. Yapılan analizler sonucu elde edilen birçok sonuç olmakla birlikte, bu bölümde her iki bölgede tüm sondajlar için elde edilen yüzey ivme grafiklerine bir kaç örnek sunulacak, daha sonra tüm davranış tepki spektrumları yardımıyla tartışılacaktır.

$\mathrm{Bu}$ örneklerden ilki Sazova mahallesi sondajlarının Erzincan ve Loma Prieta1 depremlerine ait ivme kayıtları kullanılarak eşdeğer doğrusal analizlerden elde edilmiş ivme-zaman grafikleri olup, Şekil 6'da gösterilmiştir. 3 farklı sondaj için yüzey kayıtları üstte yer almakta (yukarıdan aşağı sırasıyla, NSK14, S54 ve S56 sondajları) ve davranış değişimini tespit etmek amaciyla anakaya hareketine ait ivme-zaman grafikleri en altta sunulmaktadır.

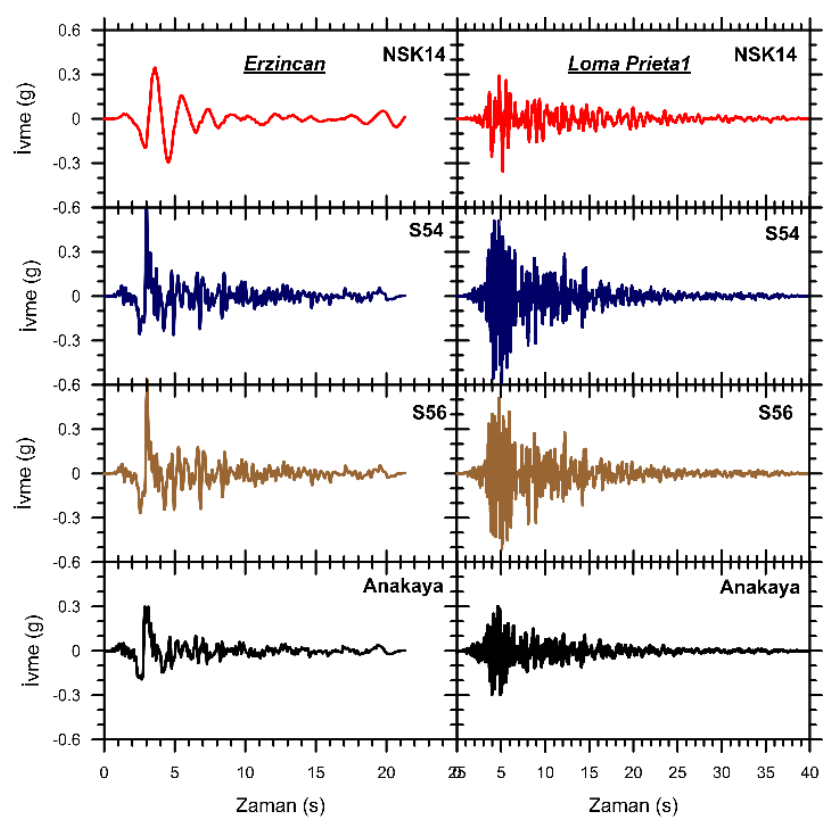

Şekil 6. S54, S56 ve NSK14 Sondajlarında Eşdeğer Doğrusal Analizlerden Elde Edilmiş İvme-Zaman Grafikleri

Genel olarak tüm ivme değerleri incelendiğinde, elde edilen pik ivmelerin büyüklügü ve bu pik ivmelerin farklı zamanlarda oluşması, farklı deprem karakteristiklerinin yansıması olarak ortaya çıkmaktadır. Çalıșmada yapılan eșdeğer doğrusal analiz sonuçlarından özetle, maksimum pik ivmeler Sazova mahallesi için daha çok S54 ve S56 sondajlarında oluşmuştur. Ancak NSK14 sondajı ise, Erzincan 1992 depreminde S54 ve S56 sondajına göre frekansı değiştiren bir davranış göstermiştir. Pik anakaya ivmesinin $0.3 \mathrm{~g}$ olduğu düşünüldüğünde S54 ve S56 profillerinin sismik davranışı yaklaşık 2 kat büyüttüğünü göstermektedir.

Şeker mahallesinde bulunan LOGSK82, LOGSK83 ve LOGSK84 sondajları Porsuk nehrinin kuzeyinde yer almaktadır. Eşdeğer doğrusal analiz çalışmaları 
sonucunda bu üç sondaja ait 11 deprem için ivmezaman grafikleri oluşturulmuştur. Şekil 7'de örnek olarak Loma Prieta 2 ve Imperial Valley 2 depremlerine ait ivme kayıt verileri kullanılarak elde edilmiş ivmezaman grafikleri sunulmaktadır. LOGSK82, LOGSK83 ve LOGSK84 sondajlarında pik ivmelerin yaklaşık $0.3 \mathrm{~g}$ ile $0.6 \mathrm{~g}$ arasında değiștiği, LOGSK83 sondajının anakaya hareketini 2 kat büyüttüğü görülmektedir. Ayrıca üç

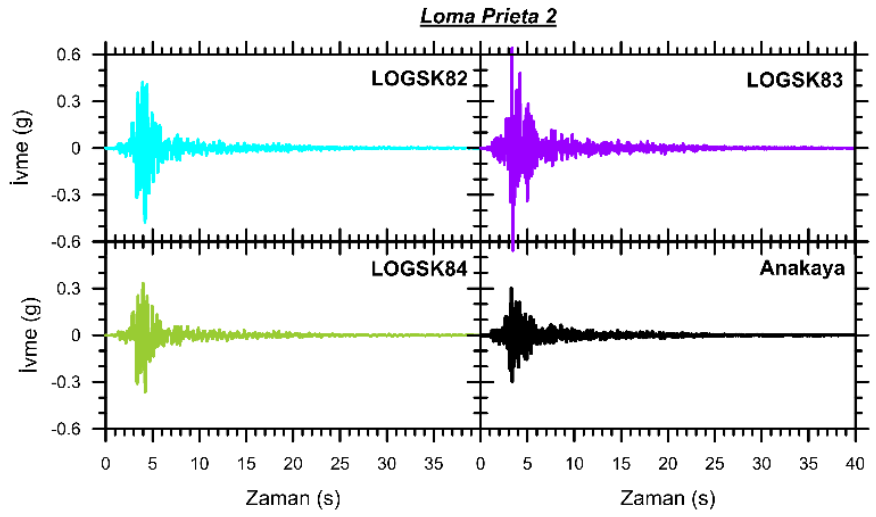

Şekil 7. LOGSK82, LOGSK83 ve LOGSK84 Sondajlarında Eşdeğer Doğrusal Analizlerden Elde Edilmiş İvme-Zaman Grafikleri

\subsubsection{Zeminin tepki spektrumu}

Eşdeğer doğrusal analizler sonucunda çalışma alanı için 11 deprem kaydına göre spektral ivme değerleri elde edilmiştir ve 66 analiz sonucu Şekil 8'de gösterilmiştir. Sonuçlar değerlendirildiğinde, 6 sondaj içerisinde maksimum spektral ivmeler Sazova mahallesinde bulunan S54 sondajında 0.35 saniyede 3.6g, S56 sondajında yaklaşı 0.45 saniyede $3.4 \mathrm{~g}$ olarak belirlenmiştir. Aynı mahallede bulunan NSK14 sondajında maksimum spektral ivme 0.8 saniyede 1.6g'dir. Maksimum spektral ivmelerin farklı periyotlarda ortaya çıkması, birbirlerine komşu sondajlar için baskın periyodun geniş bir aralıkta değerlendirmesi gerektiğini göstermektedir. Bir kaç anakaya girdi ivme sonuçlarının diğerlerinden farklı elde edilmesine rağmen, ortalama bir değerden bahsetmek mümkündür. Ancak aynı bölge ve benzer zemin özelliklerine sahip olmasına rağmen, NSK14 sondajından elde edilen davranıș; maksimum ivme, spektral ivme, süre ve periyotlar bakımından diğer iki sondajdan çok farklıdır.

Şekil 8'de LOGSK82 ve LOGSK84 sondajlarında maksimum spektral ivmenin yaklaşık 0.4-0.6 saniye aralığında 2.2-2.4 g değerlerinde olduğu, LOGSK83 sondajında ise 0.25 saniyede $4.1 \mathrm{~g}$ değerine ulaştığ belirlenmiştir. LOGSK83 zemin profili için maksimum yüzey spektrumu anakaya girdisi ile pik olarak elde edilmişken ortalama davranış genel bir periyot aralığına sondaj aynı mahallede yer almasına rağmen; aynı deprem için farklı sürelerde farklı pik ivme değerleri elde edilmiş, anakaya hareketinin frekans içerikleri değișime uğramıștır. $\mathrm{Bu}$ da tabakalanma sebebiyle sismik hareketin yukarı iletilmesi ve sönüm özelliklerinin davranışa ne derece etki ettiğini belirtmek açısından önemli bir göstergedir.

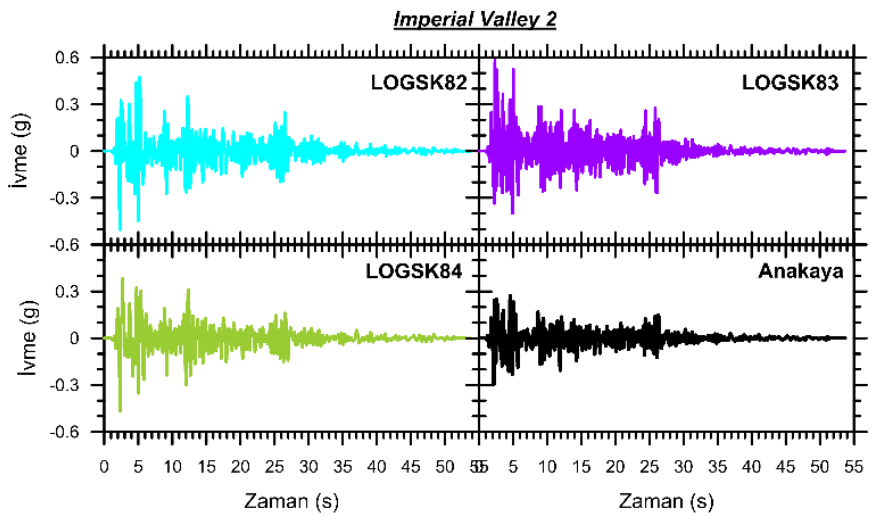
baskın bir pik değerin olmadığı ve hâkim periyotların daha geniş bir aralıkta değiștiği görülmektedir. Zemin davranışının tahmininde kullanılan yaklaşımın (eşdeğer doğrusal, doğrusal olmayan), zeminin kayma modülü ve sönüm özelliklerinin yanında farklı frekans içeriğine sahip anakaya ivmelerinin de etkili olduğu anlaşılmaktadır. 


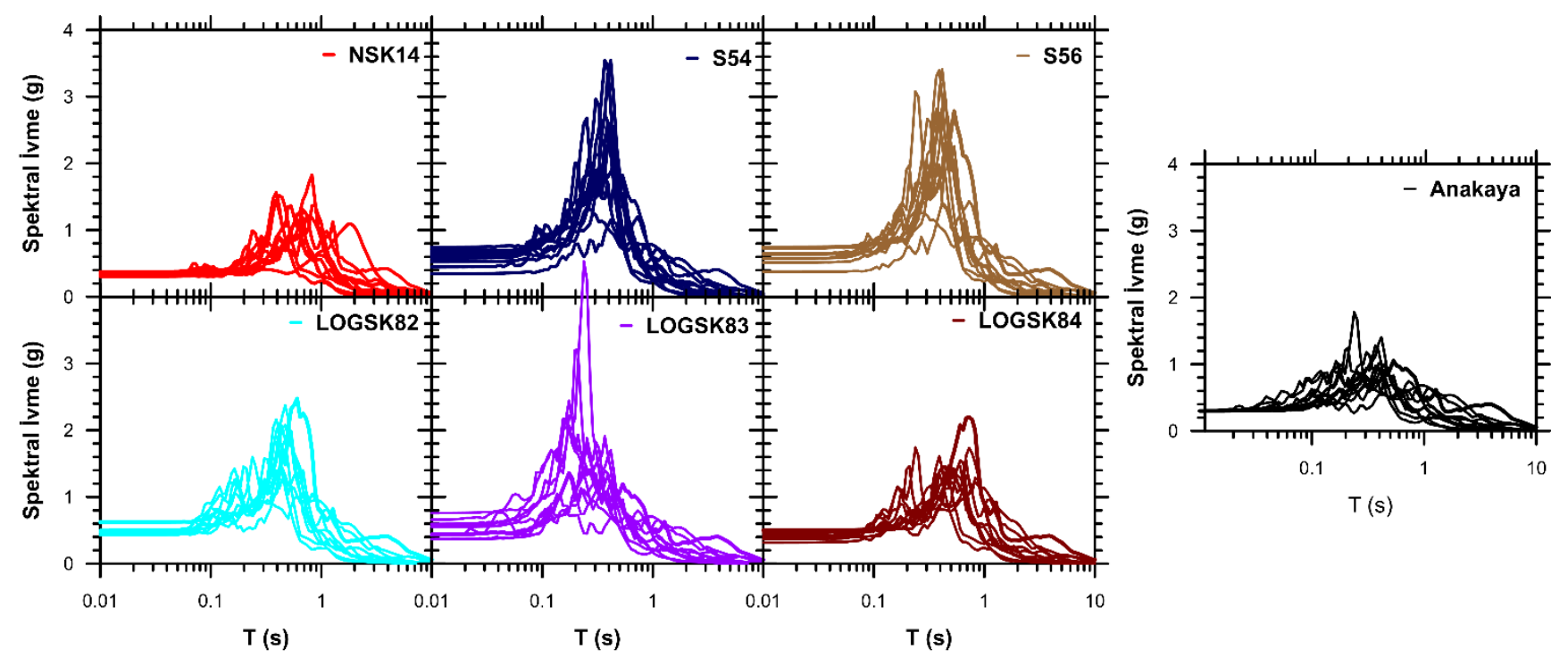

Şekil 8. Eşdeğer Doğrusal Analiz Çalışmaları Sonucunda Elde Edilmiş Spektral İvme-Periyot Grafikleri

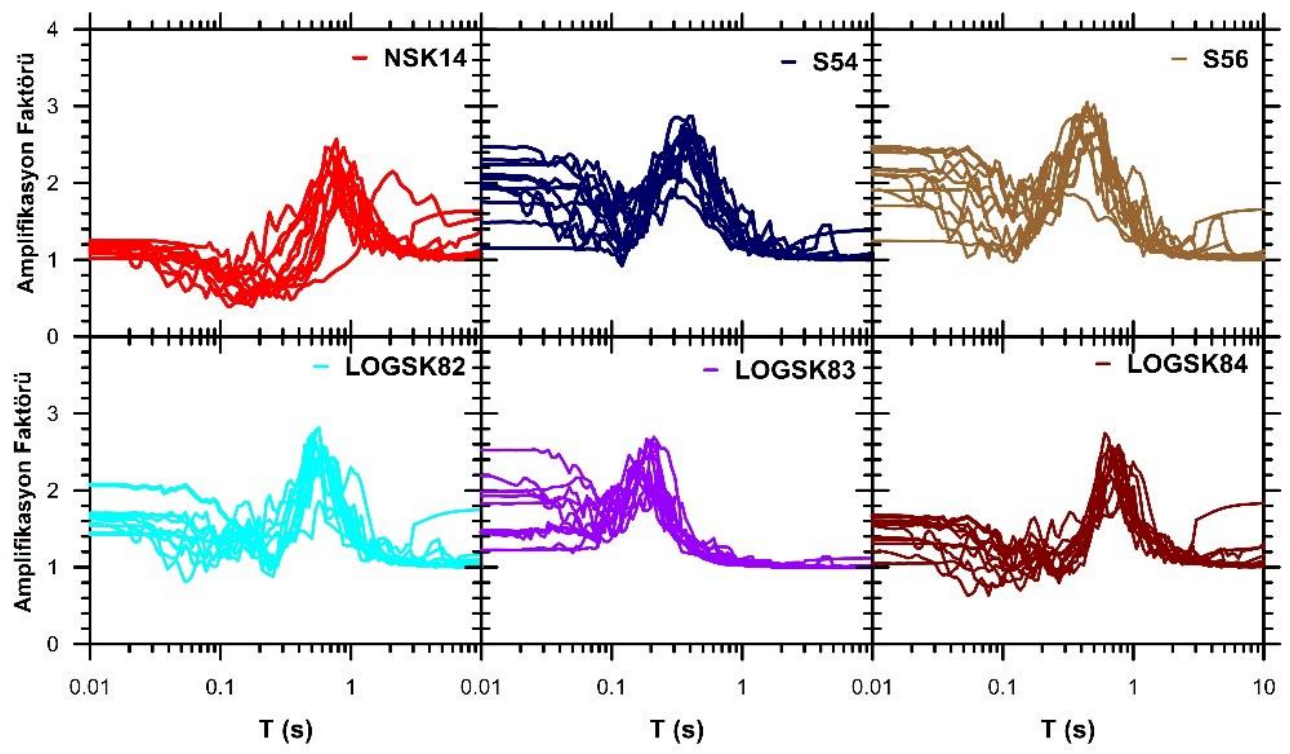

Şekil 9. Eşdeğer Doğrusal Analiz Çalışmalarından Elde Edilmiş Amplifikasyon Faktörü (Büyütme) Değerleri

\subsubsection{Zeminin büyütme değerleri}

Zemin büyütmesi, kuvvetli yer hareketi sonucunda zemin içerisinde yayılan deprem dalgalarının anakayadan yüzeye geldiklerinde genliklerinde oluşan artış olarak tanımlanır. Deprem dalgalarının etkisinde olan tabakalı yumuşak zeminlerde zemin özelliklerine bağlı olarak deprem dalgası genliklerinde büyütmelerin olduğu ve buna bağlı olarak depremin odak noktasına uzak olan bölgelerde dahi yapılarda hasarlar gözlenebilmektedir. Hasarlar, yapı hâkim periyodu ile zemin hâkim periyodunun çakışması sonucu oluşmaktadır (Cassaro, 1987). Bu nedenle amplifikasyon faktörü olarak da bilinen zeminin büyütme faktörü (oranı), depremler sırasında oluşabilecek hasarı kontrol eden bir parametredir. Büyütme oranı yüzeyde oluşan tepki spektrumunun anakaya tepki spektrumuna oranı ile elde edilmektedir. Tepki spektrumlarının yorumlanmasından sonra geleneksel olarak sunulan bir diğer grafik ise farklı periyot aralığında elde edilen büyütme oranı (amplifikasyon) değerleridir. 
Çalışmada 11 farklı depremin 6 sondaj için yapılan eşdeğer doğrusal analizleri sonucunda elde edilen amplifikasyon eğrileri Şekil 9'da sunulmaktadır. Büyütme oranlarının 2.4 ile 3.0 arasında değiştiği, en yüksek amplifikasyon faktörünün S56 sondajında 3 ve LOGSK83 sondajında 2.8; en düşük maksimum amplifikasyon faktörünün NSK14 sondajında 2.4 değeri olarak belirlenmiştir. Grafiğin üst kısmında yer alan Sazova sondajlarında $\mathrm{T}=0.01 \mathrm{~s}$ için amplifikasyon değerleri incelendiğinde, farklı depremlerde çok farklı sonuçlar elde edildiği görülmektedir. En büyük büyütmenin gerçekleştiği periyot değerleri S54 ve S56 için birbirine yakınken NSK14 sondajı için bu değer uzamıştır. Fakat Şeker mahallesi için $\mathrm{T}=0.01 \mathrm{~s}$ davranışı LOGSK82 ve LOGSK84 sondajları için daha dar bir aralığa sıkışmış olup, LOGSK83 için depremlere göre farklılı̆̆ın fazla olduğu görülmektedir. En büyük amplifikasyon oranları 3 sondajda da farklı periyotlarda gerçeklemiştir; fakat uzun periyot davranışları birbirlerine benzemektedir.

\subsection{Doğrusal Olmayan Analiz Çalışmaları Sonuçları}

Çalışmada sahaya özgü yapılan zemin tepki analizlerinde yüksek birim kayma deformasyon seviyelerinde, zeminde farklılaşan kayma modülü ve sönüm oranlarını hesaba katmak için doğrusal olmayan analizler yapılmıştır. Bu kapsamda çalışmada yapılan doğrusal olmayan zemin davranış analizlerinde; zeminin lineer olmayan davranışını göz önünde bulunduran modeller kullanılmıştır. Bu modeller; ince daneli (kil-silt) zeminler için Darendeli (2001) modeli olup iri daneli zeminler için (kum-çakıl) Seed ve Idriss (1991) modelidir.

Çalıșmada doğrusal olmayan analizler kapsamında, bir önceki bölümde verilen deprem kayıtları kullanılarak aynı sondajlar için 66 analiz gerçekleştirilmiştir.

\subsubsection{Zemin yüzeyinde oluşan ivme değerleri}

Analizlerin sonuçlarını yorumlamak amacıyla yukarıda gösterilen aynı sıralamayla, doğrusal olmayan analizden elde edilen veriler sunulmuştur. Yine örnek olarak 2 sondaj için Erzincan ve Loma Prieta1 anakaya girdilerinden yüzeyde elde edilen ivme zaman serileri Şekil 10'da gösterilmektedir. Tüm sondajlar incelendiğinde, pik yüzey ivmelerin Erzincan kaydı için yaklaşık $0.45 \mathrm{~g}$ ve Loma Prieta 1 kaydı için yaklaşık $0.5 \mathrm{~g}$ olarak tahmin edildiği saptanmıştır. Ayrıca NSK14 zemin profilinin Erzincan anakaya girdisi için davranışı büyütmediği (en büyük ivme=0.3g) ve frekans içeriğini çok değiştirmediği görülmüş, sadece sağa ufak bir ötelenme olduğu belirlenmiştir.

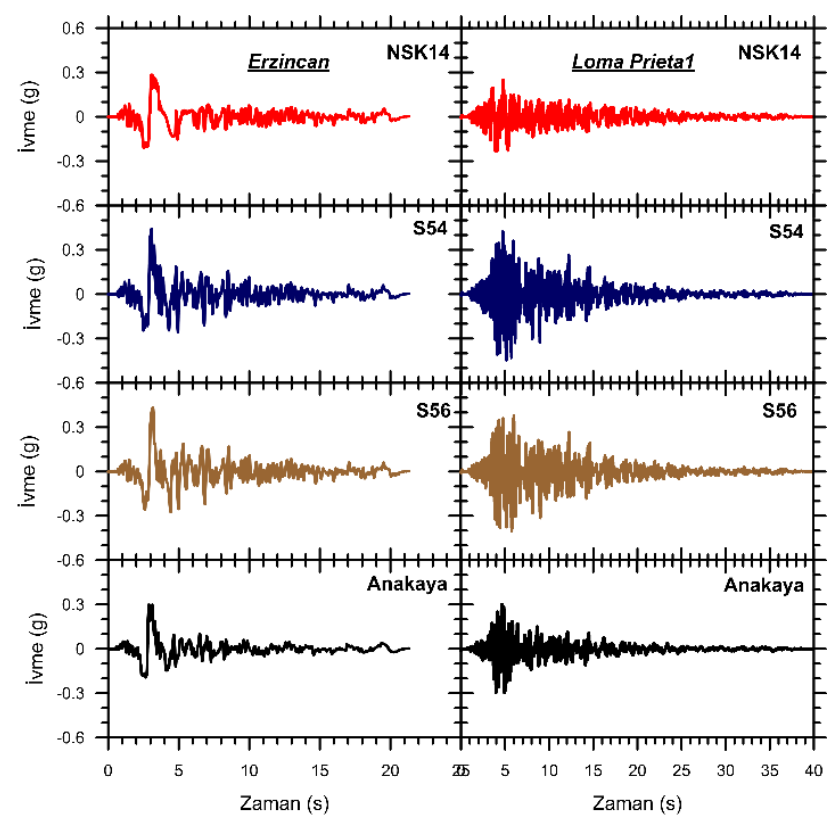

Şekil 10. S54, S56 ve NSK14 Sondajlarında Doğrusal Olmayan (Non-Lineer) Analizlerden Elde Edilmiş İvmeZaman Grafikleri

Şekil 11 'de Şeker Mahallesinde bulunan sondajlar için yapılan doğrusal olmayan analizlerden elde edilen ivmezaman grafikleri sunulmaktadır. LOGSK82, LOGSK83 ve LOGSK84 sondajlarında pik ivmelerin yaklaşık $0.3 \mathrm{~g}$ ile $0.5 \mathrm{~g}$ arasında değiștiği, en küçük pik ivmenin LOGSK84 sondajında $0.3 \mathrm{~g}$, en büyük pik ivmenin LOGSK83 sondajında $0.5 \mathrm{~g}$ olarak ortaya çıkmıştır. Şekil 11 ile Şekil 7'de gösterilmiş olan aynı deprem verilerinin aynı sondajlar için eşdeğer doğrusal analiz sonuçlarına göre karşılaştırması yapıldığında eşdeğer doğrusal analizlerden daha büyük pik ivme değerleri elde edildiği sonucuna ulaşılmıştır.

\subsubsection{Zeminin tepki spektrumu}

Çalışmada inceleme sahasında yer alan 6 sondaj için tepki spektrum parametreleri elde edilmiş, elde edilen verilerden spektral ivme ve periyot grafikleri Şekil 12'de sunulmuştur. 6 sondaj içerisinde maksimum spektral ivmenin Sazova mahallesinde bulunan S54 sondajında 0.35 saniyede yaklaşık $3.0 \mathrm{~g}$, S56 sondajında yaklaşık 0.45 saniyede $2.8 \mathrm{~g}$ olarak elde edilmiştir. Aynı mahallede bulunan NSK14 sondajinda maksimum spektral ivmenin ise $1 \mathrm{~g}$ seviyelerinde fakat geniş bir periyot aralığında oluştuğu görülmektedir. Şeker mahallesinde bulunan LOGSK83 sondajında maksimum spektral ivme 0.25 saniyede $3.8 \mathrm{~g}$, LOGSK82 ve LOGSK84 sondajlarında ise maksimum spektral ivmelerin yaklaşık 0.2-0.8 saniye aralığında $2 \mathrm{~g}$ değerlerine ulaştığı belirlenmiștir. Baskın bir pikin olmaması ve plato olarak tanımlanan düz kısmın daha geniş periyot aralıklarına yayılması üst yapı tasarım aşamasında 
dikkate alınması gereken önemli hususların başında gelmektedir. Yine eşdeğer doğrusal analizlerle kısaca kıyaslama yapıldığında, doğrusal olmayan analizler sonucu elde edilen spektral ivmelerin yaklaşık \%10 ile 20 arasında daha az olduğu belirlenmiştir.

\subsubsection{Zeminin büyütme değerleri}

Amplifikasyon oranları için, doğrusal olmayan analiz çalışmaları kapsamında elde edilen veriler Şekil 13'te gösterilmektedir. Burada maksimum büyütme oranlarının 2.0 ile 3.4 arasında değiștiği, en büyük amplifikasyonun S56 sondajında 3 ve LOGSK83 sondajında 3.4 olarak, en düşük amplifikasyonun ise NSK14 sondajlarında oluştuğu belirlenmiştir. Ayrıca eşdeğer doğrusal ve doğrusal olmayan analiz sonuçlarında göre; LOGSK83 sondajında doğrusal olmayan analizler sonucunda daha büyük amplifikasyon değerleri elde edilmiştir.
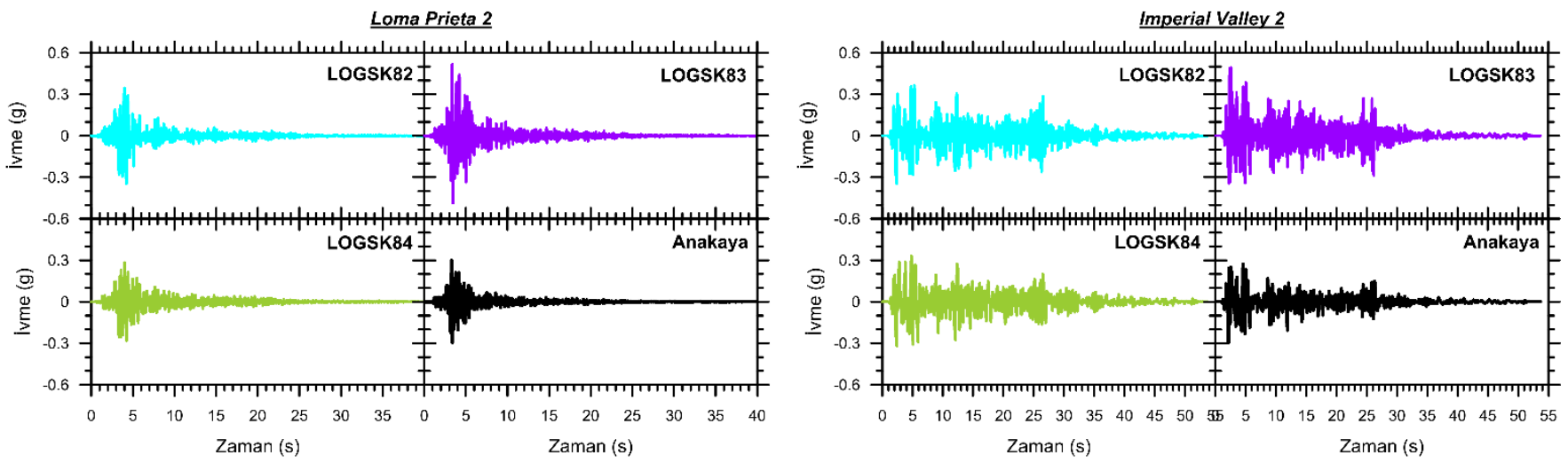

Şekil 11. LOGSK82, LOGSK83 ve LOGSK84 Sondajlarında Doğrusal Olmayan Analizlerden Elde Edilmiş İvme-Zaman Grafikleri

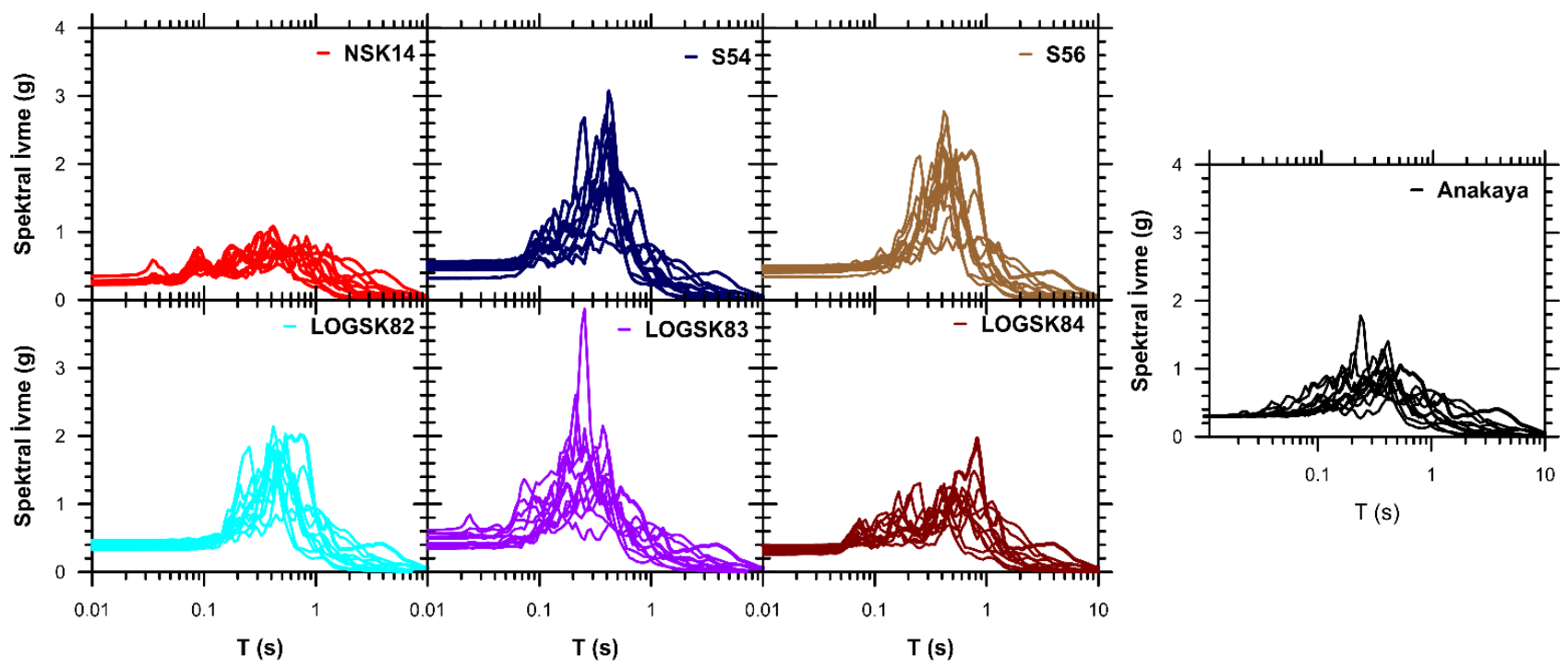

Şekil 12 Doğrusal Olmayan Analiz Çalışmalarında Elde Edilmiş Spektral İvme-Periyot Grafikleri 


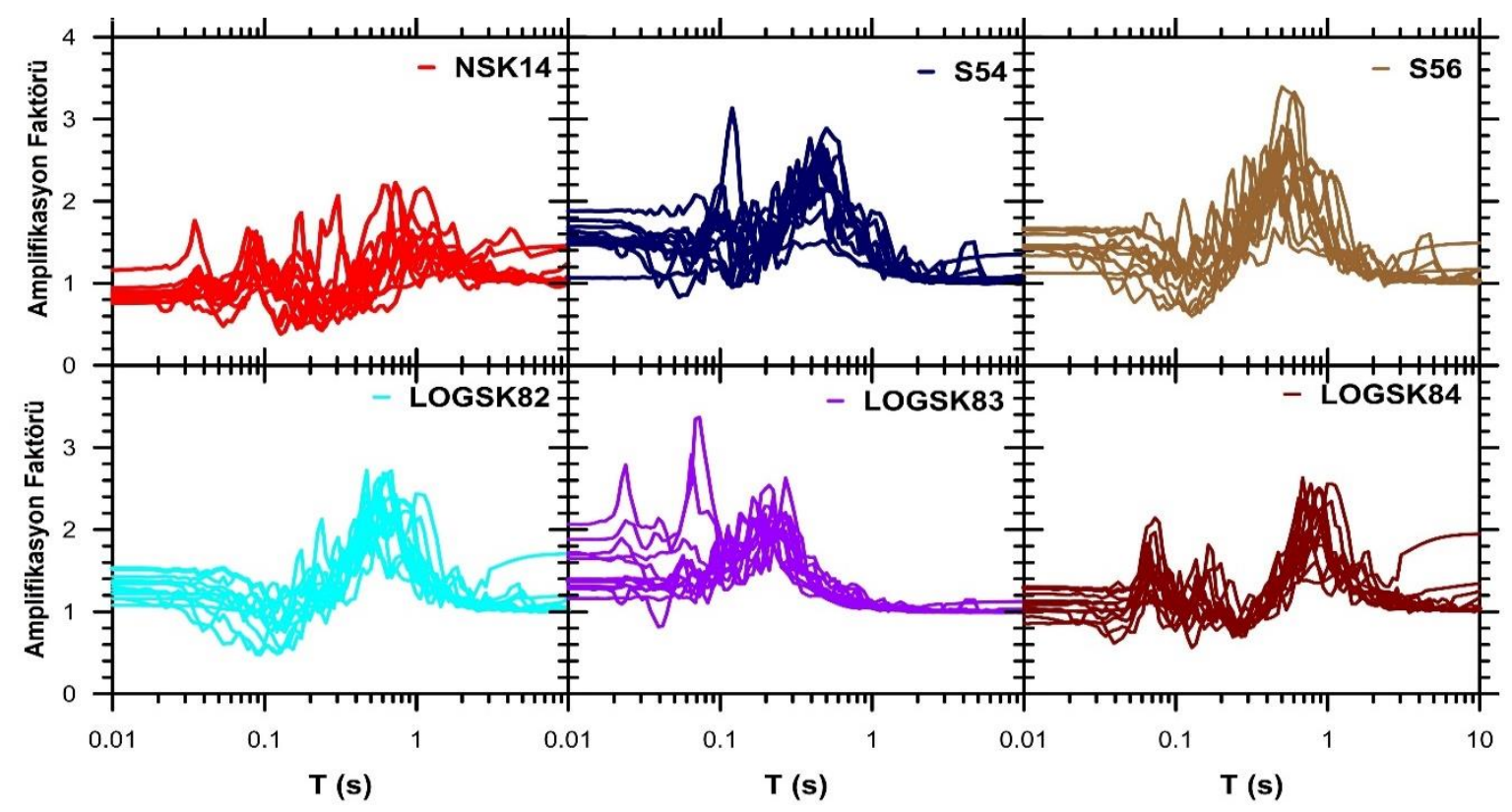

Şekil 13. Doğrusal Olmayan Analiz Çalışmalarından Elde Edilmiş Amplifikasyon Faktörü (Büyütme) Değerleri

\section{Sonuçlar}

Bu çalışma kapsamında TBDY (2018)'in önerdiği şekilde 11 farklı gerçek depreme ait ivme kaydı kullanılarak sahaya özgü eșdeğer doğrusal ve doğrusal olmayan zemin davranış analizleri gerçekleştirilmiştir. Analizler sonucunda kuvvetli yer hareketindeki spektral parametrelerin zemin yüzeyindeki değişimi belirlenmiş ve kullanılan her iki yönteme ait sonuçların bir karşılaştırması yapılmıştır.

- Ülkemizde yapı tasarımında Eskişehir için aktif kullanılan AFAD Türkiye Deprem Tehlike Haritaları İnteraktif Web Uygulamasında, çalışma alanında bulunan iki mahallenin kısa periyot ivmeleri $0.297 \mathrm{~g}-0.308 \mathrm{~g}$ arasında verilmektedir. Sahaya özel analizler sonucu, eşdeğer doğrusal ve doğrusal olmayan analizlerden elde edilen bu değerler ise $0.3 \mathrm{~g}-0.75 \mathrm{~g}$ arasında değişmektedir. Çalış̧ sonucunda özellikle S54, S56 ve LOGSK83 sondajlarında yönetmelikte yapı tasarımı için kullanıcıya sunduğu değerlere göre ortalama 2 katı büyük olan bir değer elde edilmiştir. Benzer şekilde $S_{D S}$ (yaklaşık 1.0g) değerleri göz önüne alındığında, yönetmeliğin sadece 2 sondaj için güvenlik tasarım parametresi sunduğu, diğer sondajlarda ise bu değerin çok üzerinde spektral ivmeler ortaya çıktığı gözlenmiştir. $\mathrm{Bu}$ da yerel zemin koşullarının, tabakalanmanın, ince dane oranı ve plastisite gibi özelliklerin yüzey davranışını ne derecede etkilediğini ortaya çıarmaktadır.

- Yüzey tepki spektrumları incelendiğinde, genel olarak maksimum spektral ivmelerin daha çok düşük periyotlarda gerçekleștiği; $\mathrm{T}=1$ s'den sonra ise yakın değerler gösterdiği belirlenmiştir. Ayrıca özellikle NSK14, LOGSK84 ve LOGSK82 sondajlarında maksimum spektral ivmelerin geniş bir aralıkta oluştuğu ve bu nedenle tek bir hâkim periyottan ziyade geniş bir aralığı temsil eden hâkim periyotlar görüldüğü saptanmıştır. Fakat aynı bölgeden alınan komşu sondajlarda baskın periyotlardan bahsetmek mümkün olmuştur.

- Eşdeğer doğrusal ve doğrusal olmayan analiz sonuçlarından elde edilen tüm veriler her bir sondaj için karşılaştırıldığında; eşdeğer doğrusal analiz yönteminden elde edilen sonuçların doğrusal olmayan analiz yönteminden elde edilen sonuçlara göre genelde daha büyük değerler verdiği belirlenmiştir.

- Çalışmada ZF zemin grubu olarak tanımlanan iki sondaj (LOGSK82 ve LOGSK84) için TBDY (2018)'e göre doğrusal olmayan analizlerin yapılması önerilmektedir. Çalışma kapsamında bu iki sondaj için yapılan eşdeğer doğrusal analizler ve doğrusal olmayan analizlerden elde edilen spektrum parametreleri karşılaştırıldığında eşdeğer doğrusal analizlerden daha büyük değerler elde edilmiştir. $\mathrm{Bu}$ iki sondajın zemin profilinde $10 \mathrm{~m}$ 'den sonra iri daneli olarak tanımlanan çakıllı zemin sınıfları yer almaktadır. Ancak TBDY (2018)'e göre ZE zemin grubunda bulunan, yeraltı suyu seviyesinin yüksek olduğu ve $30 \mathrm{~m}$ derinlik içinde çakıllı zemin sınıfı bulundurmayan LOGSK83 sondajında, doğrusal olmayan analiz sonuçlarından eşdeğer doğrusal analiz sonuçlarına göre daha büyük amplifikasyon değerleri elde edilmiştir. Bu nedenle ZE zemin grubunda olsa dahi, yeraltı suyu seviyesinin yüksek olduğu ve $30 \mathrm{~m}$ derinlik içerisinde çakıllı seviyelerin az olduğu ya da bulunmadığı zemin profilleri için doğrusal olmayan analizlerin yapılması tasarım 
açısından büyük önem arz etmektedir.

- Sazova Mahallesinde arazide yapılan sismik yansıma-kırılma çalışmalarında en düşük kayma dalgası hızı değerleri ölçülmüştür. Sazova mahallesinde bulunan NSK14 sondajında yapılan analizler sonucunda Erzincan depreminde frekansın değiştiği davranış göze çarpmaktadır. NSK14'ün zemin özellikleri incelendiğinde aynı mahallede yer alan diğer sondajlara göre yüksek plastisiteli ince daneli zemin sınıflarından oluştuğu görülmektedir. Burada zeminin kayma dalgası hızının da düşük olması nedeniyle, Erzincan depreminin karakteristik özelliklerinin etkisinde frekans özelliği değișmiștir.

- Sazova Mahallesinde (NSK14, S54, S56) ve Şeker Mahallesinde (LOGSK82, LOGSK83 ve LOGSK84) yer alan sondajlara bağlı yapılan analizler sonucunda, farklı spektral parametreler elde edilmiş ve en büyük amplifikasyon, farklı periyotlarda oluşmuştur. Bu nedenle yüzölçümü büyük sahalarda tek bir değerden ziyade daha çok noktada davranış analizleri yapılarak spektral parametreler belirlenmelidir.

\section{Araştırmacıların Katkısı}

Bu araștırmada; Ebru CIVELEKLER, bilimsel yayın ve literatür araştırması, verilerin elde edilmesi, eşdeğer doğrusal ve doğrusal olmayan analizlerin uygulanması ve sonuçlandırılması; Kamil B. AFACAN ve D. Volkan OKUR ise analizlerden elde edilen sonuç ve grafiklerin yorumlanması ile makalenin gelișimine fikri yönde katkı sağlamışlardır.

\section{Çıkar Çatışması}

Yazarlar tarafından herhangi bir çıkar çatışması beyan edilmemiştir.

\section{Kaynaklar}

Akdeniz, E., Güney, Y., Pekkan, E., Avdan, U., Tün, M., Ecevitoğlu, B. (2011). Temel Zeminine Ait JeoMühendislik Özelliklerin Coğrafi Bilgi Sistemi Kullanılarak Değerlendirilmesi: Eskişehir İli, Güllük, Yenibağlar ve Bahçelievler Mahalleleri Örneği. 6. International Advanced Technologies Symposium (IATS'11). Elazığ, Turkey. Erişim adresi: http://web.firat.edu.tr/iats/cd/subjects/Civil\&Cons truction/CAC-45.pdf

Akdoğan, P. (2019). Dynamic Soil Amplification In Saturated Soil Profiles Using Effective Stress Based Nonlinear Methods (Yüksek Lisans Tezi). Dokuz Eylül Üniversitesi.
Akın, M. (2009) Seismic Microzonation of Erbaa (TokatTurkey) Located Along Eastern Segment of The North Anatolian Fault Zone (NAFZ) (Doktora Tezi). Orta Doğu Teknik Üniversitesi, Jeoloji Mühendisliği, 416s.

Akgün, M., Özdağ, Ö.C., Uluğ, A., Utku, M., Erdican, B., Gönenç, Ş., Altundağ, T. K. (2015). Bayraklı Belediye Sınırları içinde Yüksek Katlı Yapılar için 1-2 Boyutlu Zemin Ana Kaya Modellerinin Tanımlanmasına Yönelik Jeolojik, Jeofizik ve Geoteknik Çalışmalar, 3. Türkiye Deprem Mühendisliği ve Sismoloji Konferansı 14-16 Ekim 2015 - DEÜ - İZMIR. Erișim adresi:http://www.tdmd.org.tr/TR/Genel/pdf2015 /TDMSK 212.pdf

Bakir B. S., Sucuoğlu H., Yilmaz, T. (2002). An Overview of Local Site Efects and the Associated Building Damage in Adapazari during the 17 August 1999 İzmit Earthquake. Bull Seismol Soc Am 92(1):509526. doi: http://dx.doi.org/10.1785/0120000819

Bolisetti, C., Whittaker, A. S., Mason, H. B., Almufti, I., Willford, M. (2014). Equivalent linear and nonlinear site response analysis for design and risk assessment of safety-related nuclear structures. Nuclear Engineering and Design, 275, 107-121. doi: http://dx.doi.org/10.1016/i.nucengdes.2014.04.033

Borcherdt RD. (1970). Effects of local geology on ground motion near San Francisco Bay. Bull Seismol Soc. Am 60, 29-61.

Carlton, B., Tokimatsu, K. (2016). Comparison of equivalent linear and nonlinear site response analysis results and model to estimate maxmum shear strain. Earthquake Engineering Research Institute, $32 \quad$ (3) 1867-1887. doi: http://dx.doi.org/10.1193/021215EQS029MR1

Cassaro, M. A., E. M. Romero ( editors ) (1987). The Mexico City Earthquake-1985, ASCE, New York.

Civelekler, E. (2020). Eşdeğer ve Doğrusal Olmayan Analiz Yöntemleri ile Zeminlerin Dinamik Davranışının Belirlenmesi (Doktora Tezi). Eskişehir Osmangazi Üniversitesi Fen Bilimleri Enstitüsü, Eskişehir.

Civelekler, E., Pekkan, E. (2021). The Applıcatıon of GIS to Determine Geotechnical Soil Model: EskisehirTepebası Area (Değerlendirmede).

Darendeli, M.B. (2001). Development of a new family of normalized modulus reduction and material damping curves. Ph.D. dissertation, University of Texas at Austin, Austin, Tex. Erişim adresi: https://repositories.lib.utexas.edu/bitstream/handl e/2152/10396/darendelimb016.pdf

Esen, E., Yakal, M., Gökçen, M., Mumcu, N., Türkman, M., Dirik, M., Çuhadar, G. (1976). Eskişehir Ve İnönü Ovaları Hidrojeoloji Haritası. T.C. Enerji Ve Tabii 
Kaynaklar Bakanlığı DSİ Jeoteknik Hizmetler Ve Yeraltısuları Dairesi Başkanlığı.

Gutenberg, B. (1957). The Effects of Ground on Earthquake Motion, Bulletion of Seismological Society of America, 47, 3, 221-251.

Gözler, M.Z., Cevher, F., Küçükayman, A. (1984-1985). Eskişehir civarının jeolojisi ve su kaynakları, MTA Dergisi, 103/104, s. 40-54, Ankara.

Gözler, M.Z., Cevher, F., Ergül, E., Asutay, H.J. (1996). Orta Sakarya ve güneyinin jeolojisi, MTA Rapor No: 9973, 87 s., Ankara.

Güney, Y., Ecevitoğlu, B., Pekkan, E., Avdan, U., Tün, M., Kaplan, O., Mutlu, S., Akdenız, E. ve ... (2013). Eskişehir Yerleşim Yerinde, CBS Teknikleri Kullanılarak Geoteknik, Yapı ve Jeofizik Bilgi Sisteminin Oluşturulması. Anadolu Üniversitesi Bilimsel Araștırma Projesi Proje No:080240.

Hashash, Y.M.A., Musgrove, M.I., Harmon, J.A., Groholski, D.R., Phillips, C.A., Park, D (2016). DEEPSOIL 6.1, User Manual, Urbana, IL, Board of Trustees of University of Illinois at Urbana-Champaign. Erişim adresi: http://deepsoil.cee.illinois.edu/ Files/DEEPSOIL User Manual v6.pdf

Kale, Ö. (2017). Tasarım Spektrumu Parametreleri için Olasılıksal Sismik Tehlike Analizlerine Bağlı Bir Çalıșma. Teknik Dergi, 28 (4), 8077-8103. dol: https://doi.org/10.18400/tekderg.331837

Kanai, K., Tanaka, T., Osada, K. (1954). Measurement of the Micro-Tremor, I, Bulletin of the Earthquake Reserach Institute, Vol. 32, Part 2, July, pp. 199-209.

Kanai, K., Tanaka, T., Yoshizawa, S. (1959). Comperative Studies of Eartquake Motions on the ground and Underground (Multiple Reflection Problems), Bulletin of the Earthquake Institute, Vol. 37, Part 1, March, pp. 53-58.

Kramer, S.L. (1996). Geotechnical Earhquake Engineering, Prentice Hall, Upper Saddle River, NJ, USA.

MacMurdo J. (1824). Papers relating to the earthquake which occurred in India in 1819. Philosophical Magazine 63:105-177.

Mutlu, S. (2012). Sismik Kırılma Yöntemi ve Mikrotremör Ölçümlerinden Elde Edilen Dinamik Zemin Parametrelerinin Coğrafi Bilgi Sistemleri (CBS) Kullanılarak Haritalanması (Yüksek Lisans ezi). Anadolu Üniversitesi, Fen Bilimleri Enstitüsü, Eskişehir.

Okur, D. V. ve Ansal, M. A. (2009). Tekrarlı Yük Etkisinde Kil Zeminlerin Lineer Olmayan Elastik Davranışı. Eskişehir Osmangazi Üniversitesi Mühendislik Mimarlık Fakültesi Dergisi, 22(1), 169-186. Erișim
adresi:https://app.trdizin.gov.tr/makale/T1RJd09U TXo/tekrarli-yuk-etkisinde-kil-zeminlerin-lineerolmayan-elastik-davranisi

Orhan, A. (2005). Eskişehir İl Merkezi Güney Bölümü Temel Zemin Birimlerinin Jeo-Mühendislik Özellikleri ve Coğrafi Bilgi Sistemi'nin Uygulanması (Doktora Tezi) Osmangazi Üniversitesi.

Ölmez, E., Demirel, Z., Uzel, Ö. F. (1986). Eskişehir Es-1 Ve Es-2 Sicaksu Sondajları Kuyu Bitirme Raporu. Enerji Hammadde Etüd Ve Arama Dairesi: Maden Tetkik Ve Arama Genel Müdürlügü.

PEER, P. E. (2006). PEER ground motion database. Berkeley: Erişim adresi: http://peer.berkeley.edu/ smcat/.

Pruiksma, J. P. (2016). Nonlinear and equivalent linear site response analysis for the groningen area. TNO Report, TNO 2016 R10460, 1-30. Erișim adresi: https://www.nlog.nl/sites/default/files/18-tno2016-r10460-nonlinear-and-equivalent-linear-siteresponse-analysis-for-the-groningen-area25032016.pdf

Roca, A., Oliveira, C. S., Ansal, A. Figueras, S. (2008). Local Site Effects and Microzonation. Geotechnical, Geological And Earthquake Engineering, 67-89. doi: http://dx.doi.org/10.1007/978-1-4020-3608-8 4

Sarıiz, K. Oruç, N. (1989). Eskişehir Yöresi'nin Jeolojisi ve Jeotermal Özellikleri. Anadolu Üniversitesi Müh. Mim. Fak. Dergisi, C.V, S.2, 59-81.

Seed, H. B., Idriss, I.M. (1991). (Mean Limit), 2017, DEEPSOIL 7.0, User Manual. Urbana-Champaing.

Selçuk, M. E., Kılıç, H., Özaydın, K. (2007). Comparison of linear and non-linear site response analysis of deep soils. Sixth National Conference on Earthquake Engineering. Istanbul, 187-198.

Tün M. (2013). Mikrobölgeleme Çalışmalarında Yer Tepkisi Ve Kayma Dalga Hiz (Vs) Yapısının Yorumlanması: Eskişehir (Doktora Tezi) İstanbul Üniversitesi Fen Bilimleri Enstitüsü, İstanbul.

Türkiye Deprem Bölgelerinde Yapllacak Binalar Hakkında Yönetmelik (2018). Afet ve Acil Durum Yönetim Başkanlığı, Ankara.

Yıldırım, A., Gürsoy, T. (1985). Eskişehir İl Merkezi Ve Yakın Çevresi Detay Jeotermal Gravite Etüdü. Maden Tetkik Ve Arama Genel Müdürlüğü. 